\title{
Sympathetic nervous regulation in patients with cirrhosis: Pathogenesis of fluid retention and formation of ascites
}

\author{
Jens H HenRiksen, MD, Helmer Ring-LARSEN, MD, Niels Juel Christensen, MD
}

JH HENRIKSEN, H RING-LARSEN, NJ CHRISTENSEN. Sympathetic nervous regulation in patients with cirrhosis: Pathogenesis of fluid retention and formation of ascites. Can J Gastroenterol 1991;5(3):103-111. Increased circulating noradrenaline in patients with cirrhosis is due to enhanced sympathetic nervous activity and is not merely the result of decreased clearance of catecholamines. There is a direct relation between the level of arterial noradrenaline and severity of cirrhosis, increased portal pressure and fluid accumulation; patients with the hepatorenal syndrome exhibit the highest values of plasma noradrenaline. In patients with cirrhosis, the kidneys have been identified as an important source of noradrenaline 'spillover' into plasma, which indicates enhanced sympathetic nervous activity in these organs. Moreover, the level of plasma noradrenaline is inversely related to renal bloodflow and urinary excretion of sodium, and directly related to plasma renin, vasopressin and aldosterone. An increased spillover of noradrenaline has recently been demonstrated in the splanchnic system and superior portosystemic collaterals. Reduced central and arterial blood volume and low arterial blood pressure secondary to peripheral vasodilation are probably important afferent stimuli for enhanced sympathetic nervous activity, although a nonvolume-dependent hepatic baroreceptor may also be present. The authors conclude that the sympathetic nervous system, in concert with other regulatory systems, plays an important role in sodium-water homeostasis and fluid retention, as well as in the systemic and hepatosplanchnic circulatory derangement seen in patients with cirrhosis. (Pour résumé, voir page 104)

Key Words: Adrenaline, Ascites, Cirrhosis, Noradrenaline, Sympathetic overactivity, Underfilling, Vasodilation

Departments of Clinical Physiology and Hepatology, Hvidovre Hospital, and Department of Internal Medicine and Endocrinology, Herlev Hospital, University of Copenhagen, Copenhagen, Denmark

Correspondence and reprints: Dr Jens H Henriksen, Associate Professor of Clinical Physiology, Department of Clinical Physiology 239, Hvidovre University Hospital, DK-2650 Huidovre, Denmark

Received for publication January 11, 1991. Accepted May 3, 1991
A DVANCED LIVER DISEASE GIVES rise to serious abnormalities in fluid dynamics and neurohumoral regulation (1). The renin-angiotensinaldosterone system, neurohypophyseal release of vasopressin and the sympathetic nervous system exhibit major changes in patients with cirrhosis. Recent reviews in these areas have dealt with renin, angiotensin, aldosterone and vasopressin (2-4). The past decade has seen a major advance in knowledge of the physiology and pathophysiology of the sympathetic nervous system. The sympathetic nervous system and circulating catecholamines are considered in this review.

Shaldon and co-workers (5), reported in 1961 that there were high levels of noradrenaline and adrenaline in the portal venous plasma of patients with cirrhosis, and suggested that catecholamines play a role in portal venous hy. pertension. However, subsequent studies with fluorometric assays were unable to confirm their bioassay finding (6-9). Fluorometric methods have now been replaced by a specific isotopederivative technique $(10,11)$ and high performance liquid chromatography (12). In a 1981 study which employed an isotope-derivative technique, the 


\section{Régulation du système nerveux sympathique chez les cirrhotiques: Pathogenèse de la rétention hydrique et formation d'ascite}

RESUME: L'augmentation de la noradrénaline circulante chez les cirrhotiques est due à l'intensification de l'activité nerveuse sympathique et ne résulte pas seulement d'une diminution de la clairance des catécholamines. Il existe un lien direct entre les taux artériels de noradrénaline et la gravité de la cirrhose, l'élévation de la pression portale et l'accumulation liquidienne; les patients atteints d'un syndrome hépato-rénal présentent les valeurs les plus élevées de noradrénaline plasmatique. Chez les patients porteurs de cirrhose, on a déterminé que les reins sont une source importante de déversement de noradrénaline dans le plasma, ce qui indique une majoration de l'activité nerveuse sympathique au niveau de cet organe. De plus, les taux plasmatiques de noradrénaline sont inversement reliés au débit sanguin rénal et à l'excrétion de sodium dans les urines, et directement reliés à la rénine, à la vasopressine et à l'aldostérone plasmatiques. Une augmentation du déversement de noradrénaline a récemment été démontrée au niveau du système splanchnique et des branches collatérales porto-systémiques supérieures. Une réduction du volume sanguin artériel et central, et une baisse de la pression artérielle consécutive à une vasodilatation périphérique constituent probablement des stimuli afférents importants, qui intensifient l'activité nerveuse sympathique bien que l'action d'un barorécepteur hépatique ne répondant pas au volume puisse aussi être incriminée. Les auteurs concluent que, chez les patients souffrant de cirrhose, le système nerveux sympathique, agissant de concert avec d'autres mécanismes de régulation, joue un rôle important dans l'homéostase sodium-eau et la rétention hydrique, ainsi que les perturbations de la circulation systémique et hépato-splanchnique.

present authors found increased levels of circulating noradrenaline and adrenaline in patients with cirrhosis and portal hypertension, which suggested that sympathetic nervous activity was enhanced in these patients (13).

The present review deals with the role of the sympathetic nervous system in homeostatic derangement, fluid retention and hemodynamic changes in the splanchnic, renal and systemic circulations in patients with cirrhosis

\section{PLASMA NORADRENALINE AND ADRENALINE}

Sympathetic activity may be assessed by measuring noradrenaline in plasma or by recording impulses in sympathetic nerves by microneurography. Noradrenaline is the main neurotransmitter of the sympathetic nervous system. It leaks from the synaptic cleft into plasma, where its concentration reflects its neurotransmitter function (11,14-16). Tungsten microelectrodes can be used to record sympathetic action potentials in human peripheral nerves at rest and during various maneuvres. A close correlation has been observed between plasma noradrenaline in forearm venous blood and sympathetic nerve activity in muscles not only at rest but also during dynamic exercise, mental stress and hypoglycemia. Both plasma noradrenaline and sympathetic nervous activity increase with age $(16,17)$.

The arterial plasma concentrations of noradrenaline and adrenaline are determined from the dynamic equilibrium between overall neuronal and adrenal 'spillover', respectively, as well as from removal of the catecholamines from organs and tissues (18-21). The metabolic clearance rate can be determined using intravenous infusion of tritium-labelled noradrenaline and adrenaline and measuring the steadystate concentration of the tracer in arterial blood. However, the clearance values thus obtained reflect the clearance of catecholamines from all tissues and organs into the systemic circulation. The clearance concept proposed by Esler et al (19) is not valid for neuronally released noradrenaline
(22). Clearance of adrenaline can be interpreted with confidence, since it can be predicted that the specific activity of adrenaline in plasma is the same as that at breakdown sites, a prerequisite for valid clearance measure. ments.

Sympathetic nervous activity in internal organs may be studied by measuring the release of noradrenaline from these organs. The difference between arterial and venous noradrenaline is corrected for extraction of noradrenaline across the organ measured using intravenous infusion of tritium-labelled noradrenaline multiplied by bloodflow to the organ $(16,20)$. Studies in animals have indicated that overspill is corre. lated to impulse activity in sympathetic nerves. Presynaptic receptors and local factors, such as bloodflow and capillary permeability, may influence noradrenaline release and overflow $(16,20)$. The effect of activation of the sympatho. adrenal system is dependent not only on impulse activity in nerves or amounts of noradrenaline and adrenaline released, but also on the responsiveness of tissue to catecholamines. This may be altered during various physiological and pathophysiological states by changes in the number and affinity of receptors, as well as by post synaptic mechanisms. Sympathetic nervous system activity is highly differentiated; sympathoadrenal activity, sensitivity to catecholamines and responsiveness should therefore be measured in specific organs or tissues.

The circulating level of noradrenaline is normal or almost normal in cirrhotic patients without fluid retention, whereas patients with ascites generally have highly elevated values $(13,23-28)$. The increased circulating noradrenaline seen in cirrhosis is caused by increased release of nor adrenaline from post ganglionic sympathetic nerve fibres because of enhanced sympathetic nervous activi. ty, and is not merely the result of decreased clearance of catecholamines in liver and other tissues $(23,29-31)$. Floras and co-workers (32) recently found a close relationship between burst frequency in sympathetic nerve fibres to skeletal muscles and circulat- 


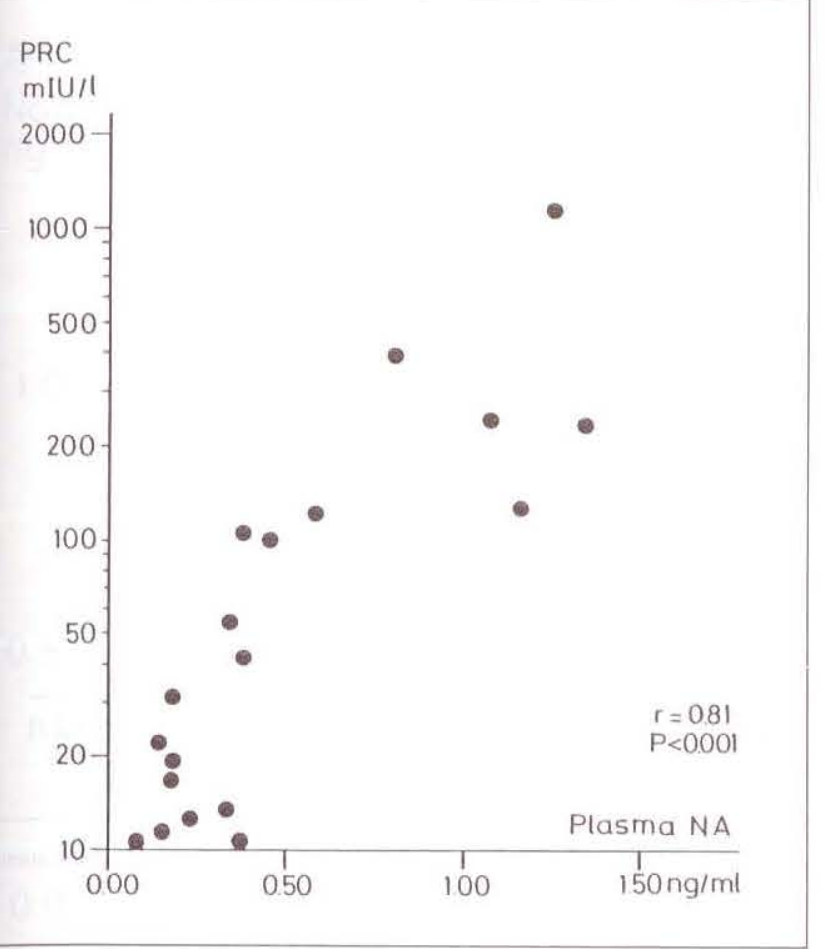

Figure 1) Relation between plasma renin concentration (PRC) and plasma noradrenaline (NA) in patients with cirrhosis. (Reproduced from reference 34)

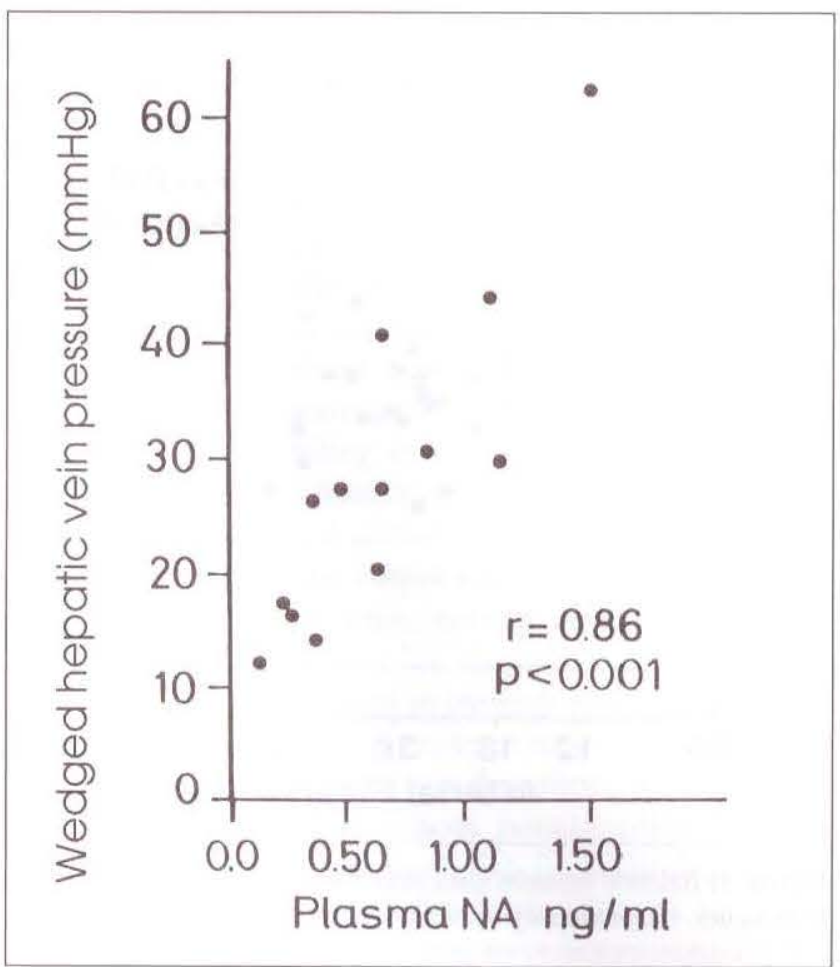

Figure 2) Relation between portal pressure (assessed as wedged hepatic vein pressure) and arterial plasma noradrenaline (NA) in patients with cirrhosis. (Reproduced from reference 13) ing noradrenaline in patients with cirthosis, thus confirming the usefulness of plasma noradrenaline as an index of sympathetic nervous activity in these patients. Diurnal variation in plasma noradrenaline and urinary excretion of noradrenaline and catecholamine metabolites indicate that even in the compensated state some patients have a moderate increase in sympathetic nervous activity (33).

In patients with cirrhosis, circulating noradrenaline is directly correlated with plasma renin activity and plasma concentrations of aldosterone and vasopressin $(24,27,34)$, indicating that the sympathetic nervous system acts in concert with other important regulatory systems (Figure 1).

\section{HEPATOSPLANCHNIC HEMODYNAMICS}

Using tritium-labelled noradrenaline, significant production and spillover of noradrenaline has recently been demonstrated in the hepatosplanchnic system of patients with cirrhosis, but not in normal subjects (35). Catheterization of the azygos vein substantiated noradrenaline spillover in the prehepatic splanchnic area and superior portosystemic collaterals, including esophageal varices (36). These results indicate that sympathetic nervous activity is enhanced in different parts of the hepatosplanchnic system, including portosystemic collaterals in patients with cirrhosis. Moreover, the arterial level of noradrenaline is directly related to portal venous pressure and azygos bloodflow (Figure 2) $(13,23,37)$.

The exact role of the sympathetic nervous system in the progression of portal hypertension and increased splanchnic bloodflow is not known; however, Mena et al (38) reported that phentolamine, an alpha-adrenergic antagonist, lowered hepatic venous wedge pressure. Clonidine, a centrally acting alpha-adrenergic blocker, decreases both circulating noradrenaline and portal pressure (37), and propranolol, a nonselective beta-adrenergic blocker, decreases portal pressure in some patients (39-43). These findings suggest that the sympathetic nervous system does play a role in portal hypertension. On the other hand, a sym- pathetic hepatic baroreceptor has been described in animal experiments, in which a primary increase in portal and sinusoidal pressure enhances sympathetic nervous activity in heart and kidney (44). Dogs with experimental cirrhosis, but without sinusoidal hypertension, do not retain sodium and water (45). That such a nonvolume-dependent hepatic baroreceptor plays a role in the increased renal sympathetic tone seen in cirrhotic patients has also been suggested (46). Thus, the sympathetic nervous system may have important afferent as well as efferent functions in the pathophysiology of hepatosplanchnic vascular derangement in cirrhosis.

\section{SODIUM-WATER HOMEOSTASIS}

Stimulation of renal sympathetic nerve fibres brings about a decrease in renal bloodflow and glomerular filtration and an increase in sodium resorption in the proximal tubules, the latter occurs because of a combination of decreased bloodflow and glomerular filtration and a direct effect on alphaadrenoceptors in the proximal tubules; 


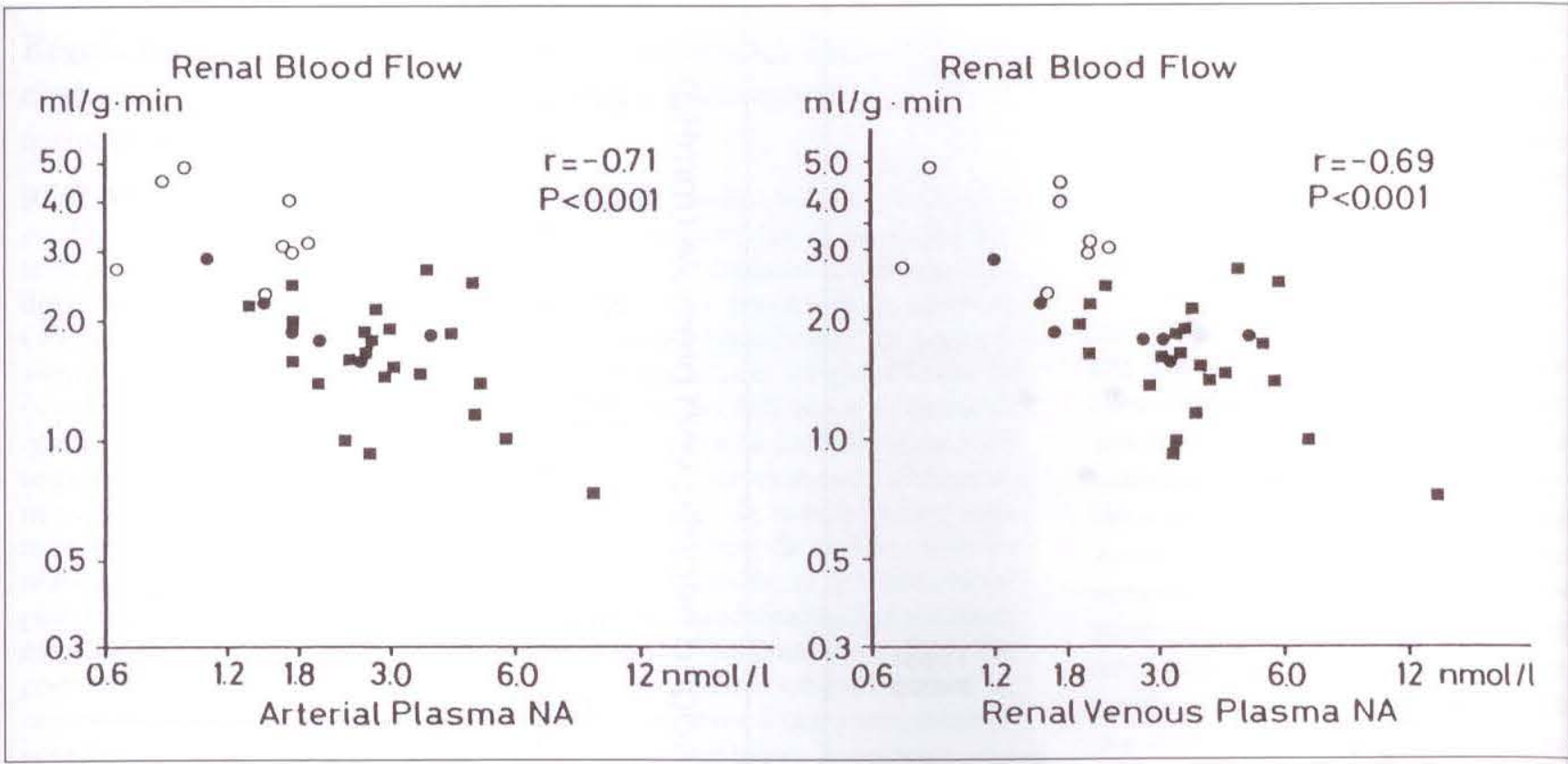

Figure 3) Relation between renal bloodflow and arterial and renal venous noradrenaline (NA)

Cirrhosis without ascites; $\bigcirc$ Controls;

Patients with ascites. (Reproduced from reference 84)

(46-50). In addition, the sympathetic nervous system activates the reninangiotensin-aldosterone system secondary to altered autoregulation, decreased delivery of sodium to the distal tubules and a direct effect on the macula densa subsequent to beta-adrenoceptor stimulation $(46-48,51,52)$.

Experiments in dogs have shown that graded stimulation of the renal nerves, increasing renal sympathetic nervous activity, causes a graded increase of noradrenaline spillover into the renal veins (53). In patients with cirrhosis, the kidneys have been identified as a major source of increased circulating noradrenaline $(13,23,25)$.

Renal bloodflow is inversely correlated with the plasma concentration of noradrenaline in the renal artery as well as the renal vein (54), which indicates that enhanced renal sympathetic nervous activity is important for renal vasoconstriction (Figure 3 ). It is still unclear at which point in the natural history of ascites the sympathetic nervous system begins to play a role. Thus, in the early stages of ascites some patients may have elevated noradrenaline, but normal renal bloodflow and glomerular filtration rate (31). Using kinetic techniques, considerable spillover of noradrenaline into renal veins has been demonstrated in most patients with fluid retention $(23,30$, 31 ), as well as a significantly negative correlation between the plasma concentration of noradrenaline and the urinary excretion of sodium (24). Moreover, there is an inverse relationship between plasma noradrenaline and the tubular rejection fraction of sodium, and it has been proposed that the sympathetic nervous tone seen in proximal tubular sodium reabsorption, independent of flow and glomerular filtration, plays a role in patients with cirrhosis (55). These results suggest that enhanced sympathetic nervous activity plays an important role in the reduced renal bloodflow and the avid sodium-water retention seen in decompensated cirrhosis and functional renal failure - the hepatorenal syndrome (56).

The hemodynamic changes point towards renal hypoperfusion being, at least initially, a normal response to changes in the systemic or splanchnic circulation, leading to decreased urinary excretion of sodium and water $(46,56)$. It seems likely that enhanced sympathoadrenal activity is a primary pathogenic factor, but several connected systems regulating hemodynamics and sodium water homeostasis are secondarily activated (2-4). Nearly all studies of these systems in chronic liver disease indicate that they counteract decreased systemic vascular resistance. In addition, increased urinary excretion of prostaglandin $\mathrm{E}_{2}$ has been observed in patients with decompensated cirrhosis; there is decreased excretion in patients with the hepatorenal syndrome. A deficit of local vasodilators such as prostaglandins has therefore been suggested as a concurrent cause of renal failure in patients with hepatorenal syndrome (27).

Stimulation of renal sympathetic nerves or infusion of noradrenaline into the renal artery in dogs has revealed that the autoregulation curve may be shifted to the right, so that renal bloodflow is diminished at a higher perfusion pressure than normal $(52,57)$ Since the renal perfusion pressure (ie, arterial mean pressure minus renal venous pressure) in advanced cirrhosis is often reduced to a critical level (about $70 \mathrm{mmHg}$ ), such a mechanism may play a role in the renal hypoper. fusion seen in patients with decompensated cirrhosis. The importance of low renal sympathetic tone and a sufficiently high renal perfusion pressure for filtration and sodium-water excretion has been demonstrated by Lenz and $c 0$. workers (58). In patients with decom. 


\section{Arterial Plasma \\ Noradrenaline Concentration $\mathrm{ng} / \mathrm{ml}$}

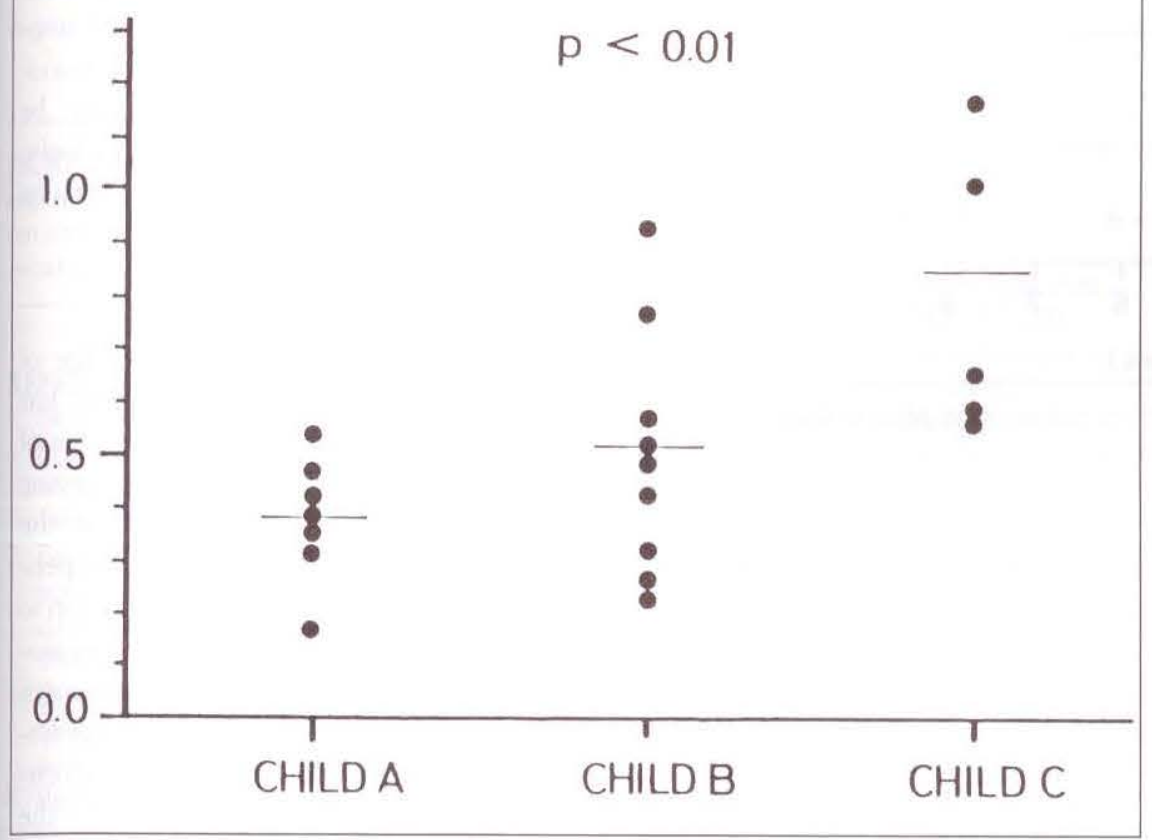

Figure 4) Circulating plasma noradrenaline and severity of cirrhosis as assessed by different Child classes (A, B and C). Normal range of arterial plasma noradrenaline: 0.08 to $0.35 \mathrm{ng} / \mathrm{mL}$. (Reproduced from reference 43)

pensated cirrhosis they demonstrated that an increase in arterial blood pressure maintained by ornithine-vasopressin infusion, increased the glomerular filtration rate from 26 to $43 \mathrm{~mL} / \mathrm{min}$ and decreased plasma noradrenaline from 1.74 to $0.87 \mathrm{ng} / \mathrm{mL}$ (indicating a fall in sympathetic nervous activity). This presumably was the result of stimulus to the arterial baroreceptors.

There is a better diuretic response in supine patients than in upright and ambulant ones; this is probably due to a decrease in enhanced sympathetic nervous activity in the supine position (59), but in the study of Ring-Larsen et al (59) it was probably due to stimulation of receptors in the venous part of the circulation. Recent animal experiments have shown that sympathetic renal denervation normalizes sodium and water excretion in experimental cirrhosis (60), and that lumbar sympathetic block improves renal function in cirrhotic patients with severely impaired renal function (61), confirming the central role of the sympathetic nervous system in the pathogenesis of ascites. Moreover, enhanced renal sympathetic nervous activity seems to play a role in the decreased responsiveness to atrial natriuretic factor observed in decompensated cirrhosis (62). This is consistent with the concept of an important sympathetic neuronal contribution to the development of refractory ascites.

Finally, increased renal sodium and water excretion follows normalization of circulating noradrenaline after implantation of a peritoneal-venous shunt (63). These results stress the vital role played by the sympathetic nervous system in fluid homeostasis in patients with cirrhosis.

\section{SYSTEMIC HEMODYNAMICS}

The level of plasma noradrenaline is directly related to the severity of circlasses (41) (Figure 4), and changes in the systemic circulation are related to deranged splanchnic hemodynamics and portal hypertension $(27,56,64,65)$. rhosis determined by Child-Turcotte
The etiology of the hyperkinetic circulation seen in cirrhosis is unknown. The finding of increased total plasma volume in human and experimental cirrhosis suggests overfilling of the circulation $(66,67)$. On the other hand, the effect of head-out water immersion or implantation of a peritoneal-venous shunt bringing about natriuresis in some patients suggests central underfilling $(63,68)$. Thus, the size of the 'effective blood volume' in cirrhosis is not settled (69). However, using cardiac output and mean circulatory transit time, central and arterial blood volume has recently been shown to be reduced in patients with cirrhosis (70) and inversely related to the level of arterial noradrenaline, as well as to renal venous noradrenaline (unpublished data). This finding indicates that 'unloaded' volume-receptors and baroreceptors may serve as a stimulus for the increased sympathetic nervous activity seen in patients with cirrhosis. In line with this theory, it has been hypothesized that peripheral arteriolar vasodilation is an initiator of enhanced sympathetic nervous activity and sodium-water retention in the presence of cirrhosis (65).

Enhanced sympathetic nervous activity is important in maintaining the level of arterial blood pressure in cirrhosis. Thus, administration of alphaadrenergic blocking agents such as phentolamine results in a decrease in the arterial blood pressure of decompensated patients, a result which underlines the importance of the sympathetic nervous system in counteracting the effect of peripheral vasodilation in cirrhosis (3,71). Beta-adrenergic blockers, such as propranolol, increase circulating noradrenaline (43), possibly due to the combined effect of a decrease in the whole-body clearance of catecholamines and a further increase in sympathetic nervous tone (36). Further enhancement of sympathetic nervous activity after beta-adrenergic blockade may be caused by: unopposed alpha-adrenergic receptors; induction of hemodynamic changes with reduced arterial blood pressure and cardiac and splanchnic flow rates; and metabolic changes (42). A relationship between 


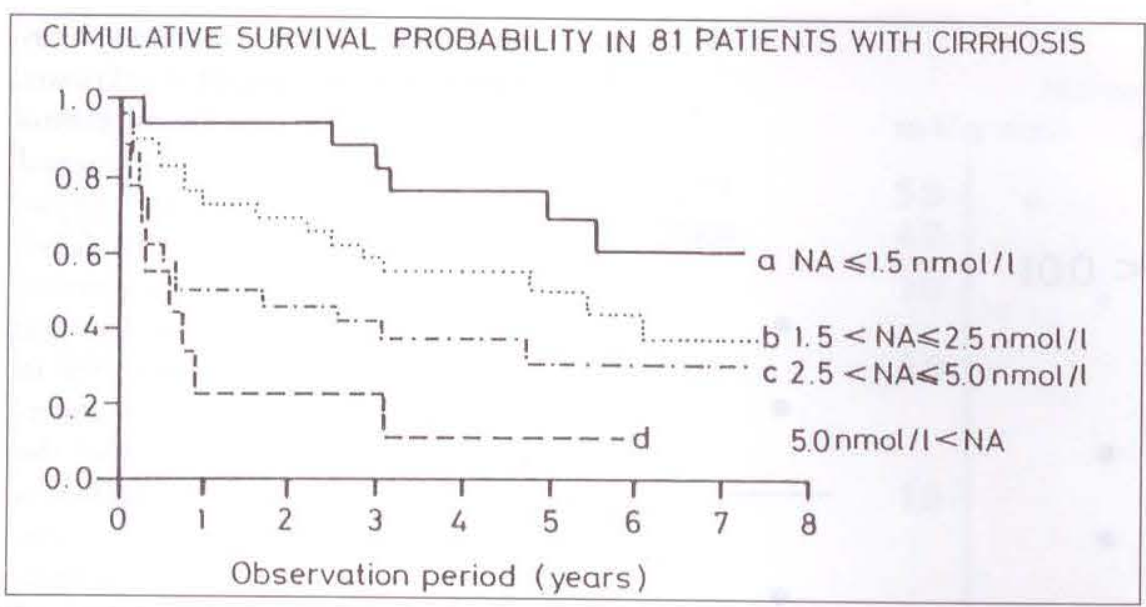

Figure 5) Cumulative survival probability in 81 cirrhotic patients with different levels of circulating noradrenaline (NA). (Reproduced from reference 88 )

sympathetic nervous activity and vasodilator systems (eg, glucagon, prostaglandins, substance $P$, enkephalins, calcitonin gene-related peptide, and endothelial-derived relaxing factor) has been described $(27,71-75)$, but the role of sympathetic nervous activity in hemodynamic adjustment and pathophysiology of the circulatory derangement seen in cirrhosis is still unclear.

\section{VASCULAR REACTIVITY AND SYMPATHETIC NEUROPATHY}

Head-up tilt increases sympathetic nervous activity and circulating noradrenaline in patients with cirrhosis (25) as well as in normal subjects. However, autonomic dysfunction in cirrhosis, owing to false or weak neurotransmitters, has been implied. Bernardi et al (28) reported that octopamine and beta-phenylethanolamine increased in parallel with noradrenaline in patients with cirrhosis during head-up tilt. The patients did not achieve an adequate cardiovascular response, and the authors concluded that hyperproduction of weak neurotransmitters was, at least in part, responsible for the attenuation. However, post synaptic alpha-adrenoceptors might already be occupied by endogenous catecholamines due to enhanced sympathetic nervous resting tone, consistent with the blunted pressor response to exogenous noradrenaline in the presence of cirrhosis (76). Reduced vascular reactivity to angiotensin II and noradrenaline has been described in experimental portal hypertension and cirrhosis $(77,78)$, but the results produced by exogenous vasoconstrictive agents on vascular reactivity in humans are conflicting. In patients with advanced liver disease, Lenz et al (79) recorded a normal increase in systolic blood pressure in response to infusion of vasoconstrictive agents, noradrenaline and angiotensin II. In fact, the response was greater than in a group of young healthy controls.

By tilting cirrhotic patients to a $60^{\circ}$ head-up position, Ring-Larsen et al (25) observed a normal noradrenaline response, ie, rapidly increasing concentrations of noradrenaline in arterial plasma. The absolute level of arterial noradrenaline was well above normal in these patients, but the increment was normal, which indicates that their volume and baroreceptor-mediated responses were intact.

Altered beta-adrenergic responsiveness may also play a role in some of the hemodynamic disturbances in liver disease. Gerbes et al (80) found evidence of decreased betaadrenoceptors in leukocytes, and Ramond et al (81) found a decreased sensitivity to isoprenaline in patients with cirrhosis. Lee et al (82) recently found evidence for a selective down-regulation of beta-1. adrenergic receptors in experimental cirrhosis whcih may be responsible for the observed myocardial hyporesponsiveness to catecholamines.

An alcoholic sympathetic neuropathy has been suggested and accord- ingly there are indications that sympathetic fibres may be damaged in alcoholics $(83,84)$. Most patients with advanced alcoholic liver disease have raised levels of circulating noradren. aline indicating a high degree of sym. pathetic reactivity, although the maximal sympathetic response may be somewhat blunted. Thus, alcoholic sympathetic neuropathy remains to be proven (85).

\section{CONCLUSIONS}

Most of the current knowledge of the sympathetic nervous system has been gained from studies of groups of patients with cirrhosis of varying severity. Longitudinal studies of the single patient from the well compensate stage to incipient fluid retention to tense ascites, and full-blown hepatorenal syndrome may reveal unknown facets of the sympathetic nervous system and other regulatory systems in cirrhosis. This holds especially true for the time course of activation of the sympathetic nervous system, the renin-angiotensin-aldosterone system, and vasopressin release. The relative contributions of these systems to main. tenance of arterial blood pressure is not sufficiently elucidated. Peripheral bloodflow (shunt flow and capillary bloodflow in skeletal muscles, sub. cutaneous tissue, fatty tissue and skin) and the coronary circulation are poorly investigated in relation to sympathetic nervous activity.

Changes in body position, physical exercise and food intake are other issues which involve the sympathetic nervous system, but knowledge is limited in patients with cirrhosis. The role of a number of other important regulatory systems, including atrial natriuretic factor, potent vasodilator systems and important humoral metabolic mediators such as insulin and glucagon, are also topics for future research. Altered renal autoregulation, false neurotransmitters, changed affinity of alpha- and beta-adrenoceptors, and autonomic neuropathy also demand further research $(86,87)$, as does renal sympathetic denervation, either surgical or pharmacological.

Although major problems are un- 
solved, it is the authors' view that the sympathetic nervous system plays a vital role in the pathophysiology of the circulatory and homeostatic derangement seen in cirrhosis (88). This view is partly borne out by the fact that the

ACKNOWLEDGEMENTS: The authors express their gratitude to Ms Bente Henriksen and Ms Grith Ingemann for their skillful secretarial help.

\section{REFERENCES}

1. Skorecki KL, Brenner BM. Body fluid homeostasis in patients with cirrhosis of the liver. Am J Med 1982; 72:323-38.

2. Better OS, Schrier RW. Disturbed volume homeostasis in patients with cirrhosis of the liver. Kidney Int 1983;23:303-11

3. Epstein M. The Kidney in Liver Disease, 3rd edn. Baltimore: Williams and Wilkins, 1988.

4. Bichet D, Szatalowicz V, Chaimovitz C, Schrier RW. Role of vasopressin in abnormal water excretion in cirrhotic patients. Ann Intern Med 1982;96:413-7.

5. Shaldon C, Peacock JH, Walker RM, Palmer DB, Badrick FE. The portal venous content of adrenaline and noradrenaline in portal hypertension. Lancet 1961;i:957-61.

6. Siegal JH, Harrison RC. Portal venous catecholamines in portal hypertension. Lancet $1963 ;$ ii: $1357-8$.

7. Evans CS, Kay W. Catecholamines in portal venous blood in portal hypertension. Lancet 1964;ii:387-8.

8. Joly J-G, Leduc J, Bernier J, Lavoire P, Viallet A. Catecholamine levels in portal, hepatic and systemic venous blood in portal hypertension. Lancet 1967;ii:121-3.

9. Cipilea A, Bubuianu E. Cerebrospinal fluid-, blood-, and ascitescatecholamines in hepatic cirrhosis. Physiologie 1979;16:19-24.

10. Christensen NJ. Plasma noradrenaline and adrenaline in patients with thyrotoxicosis and myxedema. Clin Sci 1973;45:163-71.

11. Cryer PE. Isotope-derivative measurements of plasma norepinephrine and epinephrine in man. Diabetes 1976;25:1071-85.

12. Hjemdahl P. Catecholamine measurements by high-peformance liquid chromatography. Am J Physiol 1984;247:E13-20

13. Henriksen JH, Christensen NJ, Ring-Larsen H. Noradrenaline and adrenaline concentrations in various circulating level of noradrenaline bears a close relationship to the survival of patients with cirrhosis (Figure 5) (89, 90). There may be discrete signs of autonomic sympathetic neuropathy, but most investigations of cirrhotic

vascular beds in patients with cirrhosis.

Relation to haemodynamics. Clin Physiol 1981;1:293-304.

14. Cryer PE. Workshop on catecholamines and metabolism. Am J Physiol 1984;247:E1-74,E137-220.

15. Hjemdal P. Plasma catecholamines as markers for sympathetic-adrenal activity in man: A workshop. Acta Physiol Scand 1984;(Suppl 527):1-54

16. Christensen NJ, Henriksen O, Lassen NA. The sympatho-adrenal system. Physiology and Pathophysiology. New York: Raven Press, 1986:1-512.

17. Wallin BG, Sundlöf G, Eriksson BM, Dominiak P, Grobecker H, Lindblad LE. Plasma noradrenaline correlates to sympathetic muscle nerve activity in normotensive man. Acta Physiol Scand 1981;111:69-73

18. Brown MJ, Jenner DA, Allison DT, Dolery CT. Variations in individual organ release of noradrenaline measured by an improved radioenzymatic technique; limitations of peripheral venous measurements in the assessment of sympathetic nervous activity. Clin Sci 1981;61:585-90.

19. Esler M, Willet I, Leonard P, et al. Plasma noradrenaline kinetics in humans. J Auton Nerv Syst 1984;11:125-44.

20. Christensen NJ, Henriksen JH. Degradation of endogenous catecholamines. In: Henriksen JH, ed. Degradation of Bioactive Substances: Physiology and Pathophysiology. Boca Raton: Uniscience CRC, 1991:289-305.

21. Peronnet F, Beliveau L, Boudreau G, Trudeau F, Brisson G, Nadeau R. Regional plasma catecholamine removal and release at rest and exercise in dogs. Am J Physiol 1988;254:R663-72.

22. Christensen NJ, Henriksen JH. Total norepinephrine spillover.

Hypertension 1988;12:468-9.

23. Henriksen JH, Ring-Larsen $H$, Kanstrup I-L, Christensen NI. Splanchnic and renal elimination and release of catecholamines in cirrhosis. Evidence of enhanced sympathetic nervous activity in patients with decompensated cirrhosis. Gut 1984;25:1034-43.

24. Bichet DG, Van Putten VJ, Schrier RW. Potential role of increased sympathetic activity in impaired patients point to an intact sympathetic nervous system, highly activated secondary to chronic stimulation of volume receptors and baroreceptors, as a result of underfilling of the central and arterial parts of the circulation.

sodium and water excretion in cirrhosis. N Engl J Med 1982;307:1552-7.

25. Ring-Larsen $H$, Hesse B, Henriksen JH, Christensen NJ. Sympathetic nervous activity and renal and systemic hemodynamics in cirrhosis - Plasma norepinephrine concentration, hepatic extraction, and renal release. Hepatology 1982;2:304-10,

26. Burghardt W, Wernze H, Schaffrath I. Changes of circulating noradrenaline and adrenaline in hepatic cirrhosis Relation to stage of disease, liver and renal function. Acta Endocrinol 1982;99(Suppl 246):100-1.

27. Arroyo V, Planas R, Gaya J, et al. Sympathetic nervous activity, renin-angiotensin system and renal excretion of prostaglandin E-2 in cirrhosis. Relation to functional renal failure and sodium and water excretion. Eur J Clin Invest 1983;13:271-8.

28. Bernardi M, Trevisiani F, Santini C, et al. Plasma norepinephrine weak neurotransmitters, and renin activity during active tilting in liver cirrhosis: Relationship with cardiovascular homeostasis and renal function. Hepatology 1983;3:56-64.

29. Nicholls KM, Shapiro MD, Van Putten VJ, et al. Elevated plasma norepinephrine concentrations in decompensated cirrhosis. Association with increased secretion rates, normal clearance rates, and suppressibility by control blood volume expansion. Circ Res 1985;56:457-61.

30. Willet I, Esler M, Burke F, Leonard P, Dudley F. Total and renal sympathetic nervous system activity in alcoholic cirrhosis. J Hepatol 1985;1:639-48.

31. Henriksen JH, Christensen NJ, Ring-Larsen $\mathrm{H}$. Continuous infusion of tracer norepinephrine may miscalculate unidirectional nerve uptake of norepinephrine in man. Circ Res 1989;65:388-95.

32. Floras JS, Legault L, Morali GA, Hara $\mathrm{K}$, Blendis LM. Increased sympathetic outflow in cirrhosis and ascites: Direct evidence from intraneural recordings. Ann Intern Med 1991;114:373-80.

33. Bernardi M, Trevisoni F, DePalma R, et al. Chronolobiological evaluation of sympathoadrenergic function in cirrhosis. Relationship with arterial pressure and heart rate. 
Gastroenterology 1987;93:1178-86.

34. Henriksen JH, Ring-Larsen H, Christensen NJ. Plasma noradrenaline in patients with liver cirrhosis in relation to ascites and treatment. Clin Physiol 1981;(Suppl 1):66-70.

35. Henriksen JH, Ring-Larsen H, Christensen NJ. Hepatic intestinal uptake and release of catecholamines in alcoholic cirrhosis. Evidence of enhanced hepatic intestinal sympathetic nervous activity. Gut 1987;28:1637-42.

36. Bendtsen F, Christensen NJ, Sørensen TIA, Henriksen JH. Effect of oral propranolol on azygos, renal and hepatic uptake and output of catecholamines in cirrhosis. Hepatology, (In press)

37. Moreau R, Lee SS, Hadenque A, Braillon LA, Lebrec D. Hemodynamic effect of a clonidine-induced decrease in sympathetic tone in patients with cirrhosis. Hepatology 1987;7:149-54.

38. Mena I, Orrego H, Baraona E, Maques $\mathrm{S}$. Effect of regitine and reserpine on portal hypertension. Am J Dig Dis 1963;8:895-903.

39. Lebrec D, Nouel O, Corbic M, Benhamou J-P. Propranolol. A medical treatment for portal hypertension? Lancet 1980;ii:180-2.

40. Bosch J, Masti R, Kravetz D, et al. Effects of propranolol on azygos venous blood flow and hepatic and systemic hemodynamics in cirrhosis. Hepatology 1984:4:1200-5.

41. Garcia TG, Grace ND, Groszmann RJ, et al. Short term effect of propranolol on portal venous pressure. Hepatology 1986;6:101-6.

42. Bendtsen F, Henriksen JH, Becker U, Sørensen TIA. Effect of oral propranolol on splanchnic oxygen uptake and haemodynamics in patients with cirrhosis. J Hepatol 1987;5:137-43.

43. Bendtsen F, Henriksen JH, Sørensen TIA, Christensen NJ. Effect of oral propranolol on circulating catecholamines in cirrhosis.

Relationship to severity of liver disease and splanchnic haemodynamics. J Hepatol 1990;10:198-204.

44. Kostreva DR, Castaner A, Kampine JP. Reflex effect of hepatic baroreceptors on renal and cardiac sympathetic nerve activity. Am J Physiol 1980;238:R390-4.

45. Unikowsky B, Wexler MJ, Levy M. Dogs with experimental cirrhosis of the liver but without intrahepatic hypertension do not retain sodium or form ascites. J Clin Invest 1983;72:1594-604.

46. DiBona FG. Renal neural activity in hepatorenal syndrome. Kidney Int 1984;25:841-53.
47. DiBona GF. Neurogenic regulations of renal tubular sodium re-absorption. Am J Physiol 1977;233:F73-81.

48. DiBona GF. The functions of the renal nerves. Rev Physiol Pharmacol 1982;94:75-181.

49. Prosnitz EH, DiBona GF. Effect of decreased renal sympathetic nerve activity of renal tubular sodium reabsorption. Am J Physiol 1978;235:F551-63.

50. Bello-Ruess E. Effect of catecholamines in fluid reabsorption by the isolated proximal convoluted tubule. Am J Physiol 1980;238:F347-52.

51. Vandongen R, Pearl WS, Boyd QW. Adrenergic stimulation of renin secretion in the isolated perfused rat kidney. Circ Res 1973;32:190-6.

52. Langaard $\varnothing$, Holdaas H, Eide I, Kill F Conditions for humoral alphaadrenoceptor stimulation of renin release in anaesthetized dogs. Scand J Clin Lab Invest 1981;41:527-34.

53. Kopp U, Bradley T, Hjemdahl P. Renal venous outflow and urinary excretion of norepinephrine, epinephrine and dopamine during graded renal nerve stimulation. Am J Physiol 1983;244:E52-60.

54. Ring-Larsen $\mathrm{H}$, Henriksen JH, Christensen NJ. Prerenal failure. N Engl J Med 1989;320:397-8.

53. Bernardi M, Santini C, Trevisani F. Renal function impairment induced by change in posture in patients with cirrhosis and ascites. Gut 1985;26:629-35.

56. Ring-Larsen H. Hepatic nephropathy, related to haemodynamics. Liver 1983;3:265-89.

57. Finke R, Gross R, Hackenthall E, Huber J, Kirchheim HR. Threshold pressure for the pressure-dependent renin release in the autoregulating kidney of conscious dogs. Pflugers Arch 1983;39:102-10.

58. Lenz K, Hörtnagl H, Druml W, et al. Beneficial effect of 8-ornithine vasopressin on renal function in decompensated cirrhosis. Gut 1989;30:90-6.

59. Ring-Larsen $\mathrm{H}$, Henriksen JH, Wilken C, Clausen J, Pals H, Christensen NJ. Diuretic treatment in decompensated cirrhosis and congestive heart failure: Effect of posture. Br Med ] 1986;292:1351-3.

60. Zambraski E, O'Hagan K, Thomas G, Hora D. Chronic renal denervation prevents sodium retention in cirrhotic miniature swine. Proceedings of International Meeting on Liver and Kidney Diseases, Florence, 1990:15.

61. Solis-Herruso JA, Duran A, Favela V, et al. Effects of lumbar sympathetic block on kidney function in cirrhotic patients with hepatorenal syndrome. J Hepatol 1987; 5:167-73.

62. Morali GA, Floras JS, Legault L, Logar AG, Skorecki KL, Blendis LM. Atrial natriuretic factor (ANF) responsiveness in compensated and decompensated cirrhosis: The role of the sympathetic nervous system (SNS). Hepatology 1990;12:856.

63. Blendis LM, Sole DP, Campbell P, et al. The effect of peritoneovenous shunting on catecholamine metabolism in patients with hepatic ascites. Hepatology 1987;7:143-8.

64. Epstein M, Berg DF, Hollenberg NK. Renal failure in the patient with cirrhosis - The role of active vasoconstriction. Am J Med 1970;49:175-98.

65. Schrier RW, Arroyo V, Bernardi M, Epstein M, Henriksen JH, Rodés J. Peripheral arterial vasodilation hypothesis: A proposal for the initiation of renal sodium and water retention in cirrhosis. Hepatology 1988;5:1151-7.

66. Lieberman FL, Denison EK, Reynolds TB. The relationship of plasma volume, portal hypertension, ascites, and renal sodium retention in cirrhosis. The overflow theory of ascites formation. Ann NY Acad Sci 1970;170:202-12.

67. Levy M, Allotey JBK. Temporal relationship between urinary salt retention and altered systemic hemodynamics in dogs with experimental cirrhosis. J Lab Clin Med 1978;92:560-9.

68. Epstein M. The sodium retention of cirrhosis. A reappraisal. Hepatology 1986;6:312-5.

69. Epstein FH. Underfilling versus overfilling in hepatic ascites. $\mathrm{N}$ Engl ] Med 1982;307:1577-8.

70. Henriksen JH, Bendtsen F, Sørensen TIA, Stadeager C, Ring-Larsen H. Reduced central blood volume in cirrhosis. Gastroenterology 1989;97:1506-13.

71. Hörtnagl H, Singer EA, Lenz K. Substance $P$ is markedly increased in plasma of patients with hepatic coma. Lancet $1984 ; i: 480-3$.

72. Thornton JR, Dean H, Losowsky MS Is ascites caused by impaired hepatic inactivation of blood borne endogenous opioid peptides? Gut 1988;29:1167.

73. Ames RP, Borkowsky AJ, Siciuski AM, Laragh JH. Prolonged infusions of angiotensin II and norepinephrine and blood pressure, electrolyte balance, and aldosterone and cortisol secretion in normal man and in cirrhosis with ascites. J Clin Invest 1965;44:117-24

74. Bendtsen F, Shifter S, Henriksen JH. Increased circulating calcitonin 
gene-related peptide (CGRP) in cirrhosis. J Hepatol 1991;12:118-23.

75. Vallance P, Moncada S.

Hyperdynamic circulation in cirrhosis: A role for nitric oxide? Lancet 1991;337:776-8.

76. Murray BM, Paller MS. Decreased pressor reactivity to angiotensin II in cirrhosis in cirrhotic rats. Evidence for a post-receptor defect in angiotensin action. Circ Res 1985;57:424-31.

77. Bomzom A, Blendis LM. Vascular reactivity in experienced portal hypertension. Am J Physiol 1987;252:G158-62.

78. Mashford ML, Makow WA, Chalmers TC. Studies of the cardiovascular system in the hypotension of liver failure. N Engl J Med 1962;267:1071-6.

79. Lenz K, Hörtnagl H, Magometschnigg D, Kleinberger G, Druml W, Lagger A. Function of the autonomic nervous system in patients with hepatic encephalopathy. Hepatology 1985;5:831-6.

80. Gerbes AL, Remien I, Jungst D, Sauerbruch T, Paumgartner G. Evidence for a down regulation of beta-2-adrenoceptors in cirrhotic patients with severe ascites. Lancet 1986;i:109-10.

81. Ramond MJ, Comoy E, Lebrec D. Alternations in isoprenaline sensitivity in patients with cirrhosis: Evidence of abnormality of the sympathetic nervous activity. $\mathrm{Br} J$ Pharmacol 1986;21:191-6.

82. Lee S, Marty J, Mantz J, Samain E, Braillon A, Lebrec D. Desensitization of myocardial beta-adrenergic receptors in cirrhotic rats. Hepatology 1990;12:481-5.

83. Novak DJ, Victor M. The vagus and sympathetic nerves in alcoholic polyneuropathy. Arch Neurol 1974;30:273-8.

84. Eisenhofer G, Whiteside EA, Johnson RH. Plasma catecholamine responses to change of posture in alcoholics during withdrawal and after continued abstinence from alcohol. Clin Sci 1985;64:71-8.

85. MacGilchrist AJ, Reid JL. Impairment of autonomic reflexes in cirrhosis. J Gastroenterol 1990;85:288-92.

86. Henriksen JH, Ring-Larsen H,
Christensen NJ. Sympathetic nervous activity in cirrhosis. A survey of plasma catecholamine studies. J Hepatol 1985; 1:55-65.

87. Henriksen JH, Ring-Larsen $\mathrm{H}$, Christensen NJ. Autonomic nervous function in liver disease. In: Blendis LM, Bomzom A, eds. Cardiovascular Complication of Liver Disease. Boca Raton: CRC Press Inc, 1990:63-79.

88. Henriksen JH, Ring-Larsen H, Christensen NJ. Aspects of sympathetic nervous system regulation in patients with cirrhosis. A 10 -years experience. Clin Physiol. (In press)

89. Llach J, Gines P, Arroyo V, Tito L, Badalamenti A, Jimenez W. Prognostic value of arterial pressure endogenous vasoactive systems, and renal function in cirrhosis with ascites. Gastroenterology 1988;94:482-7.

90. Tage-Jensen U, Henriksen JH, Christensen E, Widding A, Ring-Larsen H, Christensen NJ. Plasma catecholamine level and portal venous pressure as guides to prognosis in patients with cirrhosis. J Hepatol 1988;6:350-8 


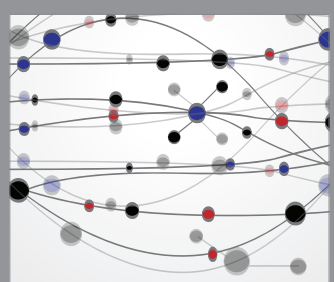

The Scientific World Journal
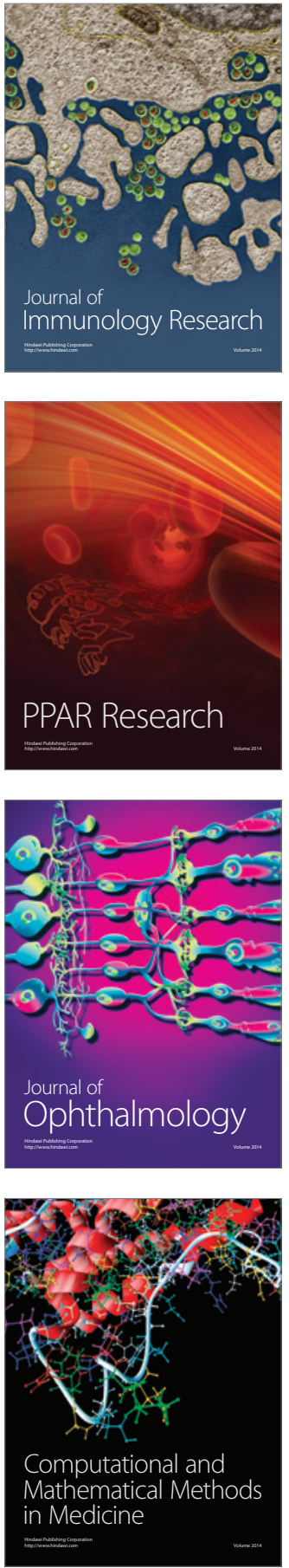

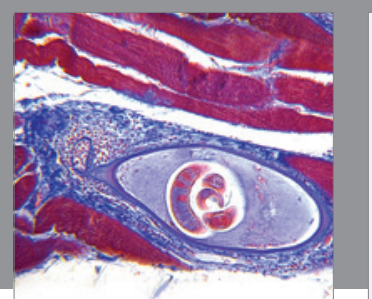

Gastroenterology Research and Practice

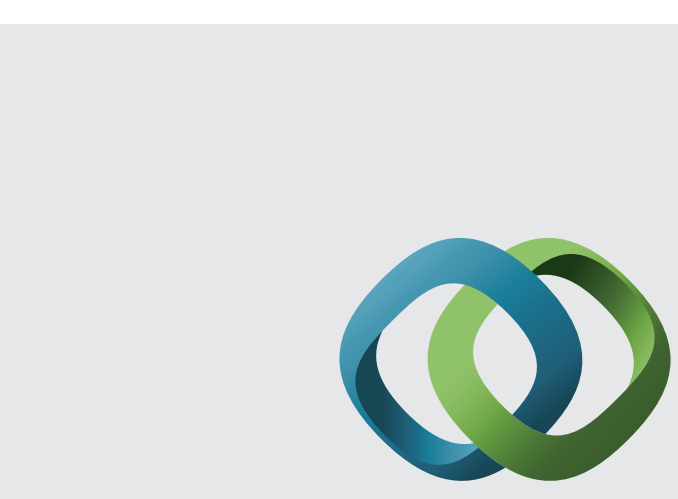

\section{Hindawi}

Submit your manuscripts at

http://www.hindawi.com
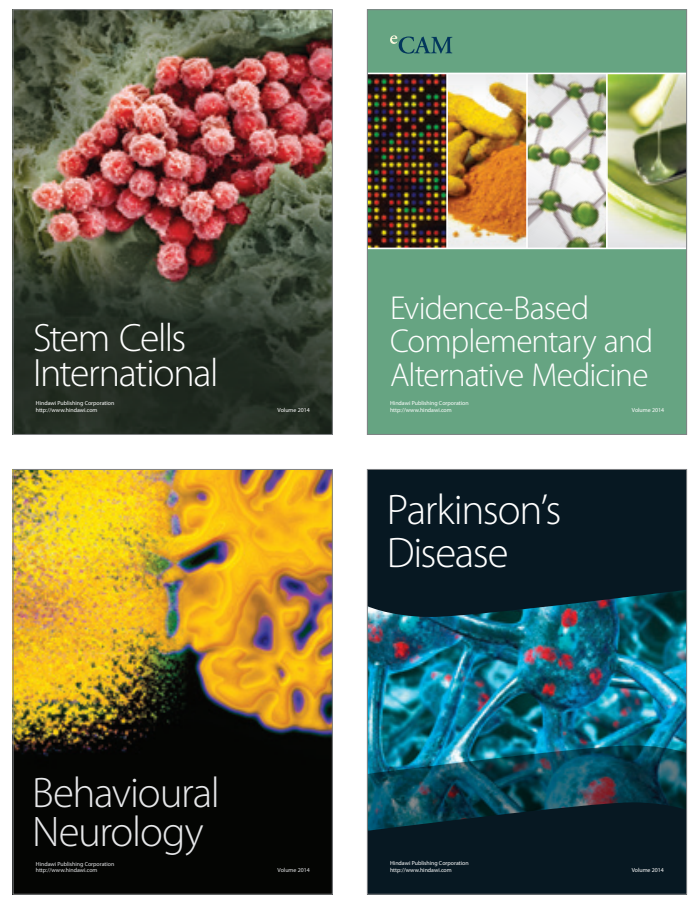
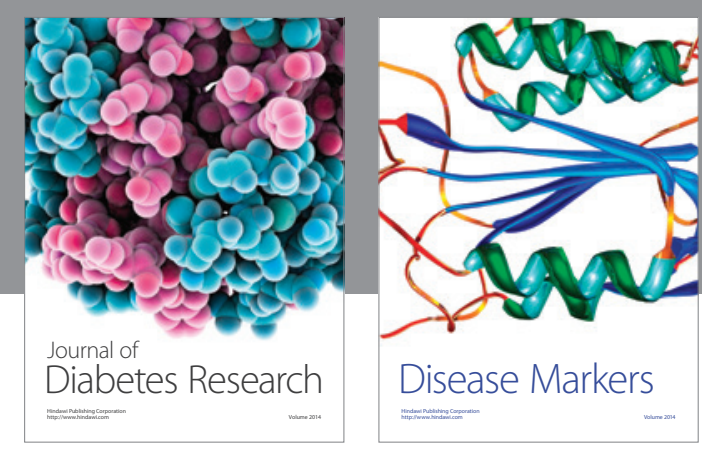

Disease Markers
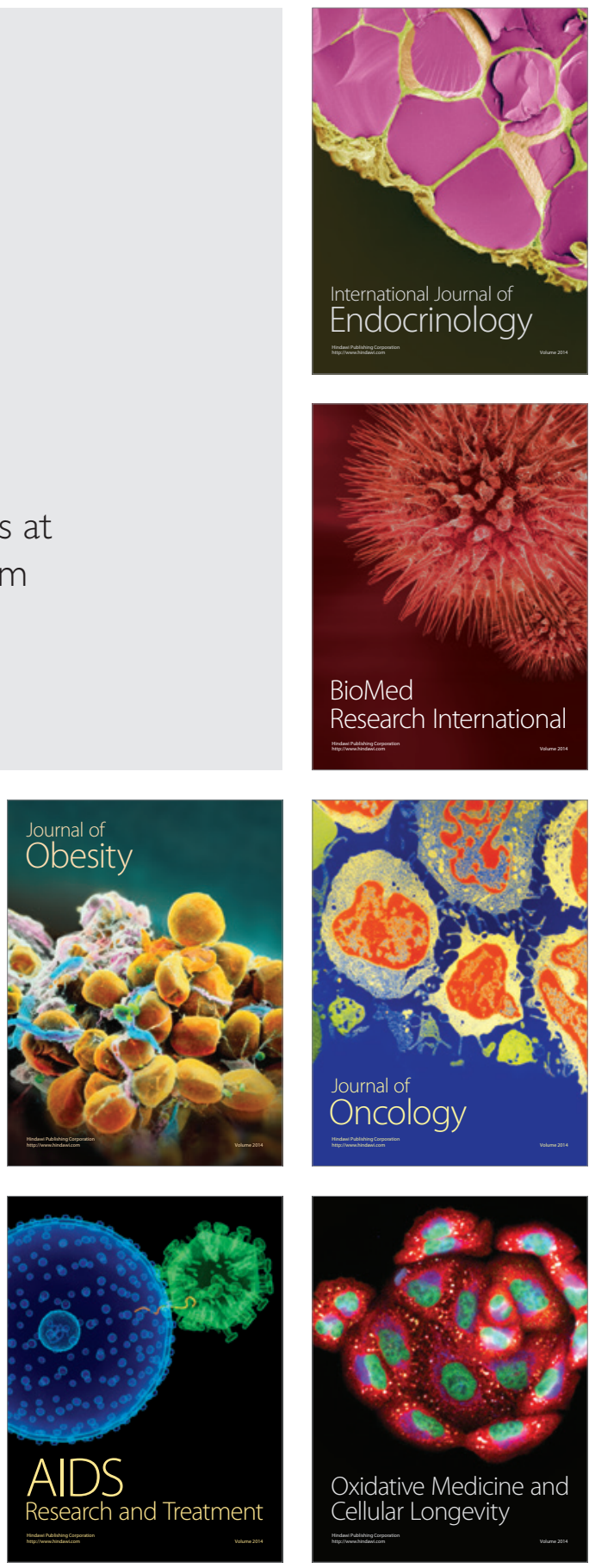